\title{
PEMASARAN PRODUK TERHADAP APLIKASI INSTAGRAM KEPADA WARGA PERUMAHAN VILLA CASABLANCA SAWANGAN DEPOK
}

\author{
Imam Himawan ${ }^{1)}$, Syatantra Rahutama ${ }^{2)}$ \\ Program Studi Informatika, Fakultas Teknik dan Ilmu Komputer, \\ Universitas Indraprasta PGRI
}

\begin{abstract}
Abstrak
Marketplace yang tersedia begitu banyak serta metode penggunaan e-commerce implementasi begitu banyak sehingga dapat memudahkan seseorang untuk meningkatkan kemampuan baik dalam pembelajaran dari sumber dan informasi yang di dapat terhadap rasa ingin tahu serta mendemokanya. Bertujuan untuk memberikan ilmu pengetahuan masyarakat warga perumahan villa Casablanca. Aplikasi social media sebagai contoh instagram didalamnya terdapat fitur - fitur yang memudahkan seseorang dalam memulai usaha lewat media e-commerce baik dalam mempromosikan produk serta penggunaan aplikasi, serta masyarakat mengetahui, oleh karena itu kami melakukan pendekatan mengadakan pembelajaran dalam rangka pengabdian kepada masyarakat untuk mensosialisasikan aplikasi instagram dan menerapkannya pada device mobile (smartphone) dan laptop atau device center seperangkat alat CPU yang digunakan oleh warga Perumahan Villa Casablanca, Sawangan Depok, Jawa Barat. Dan kami juga memberikan pelatihan pengunaan fitur aplikasi istagram social media pada smartphone android, dan juga kami memberikan informasi cara menggunakan aplikasi tersebut yang bertujuan untuk mengetahui teknik pemasaran produk. Dari kegiatan pengabdian masyarakat ini, para warga Perumahan Villa Casablanca, Sawangan Depok, Jawa Barat.
\end{abstract}

Kata kunci: e-commerce, pemanfaatan aplikasi social media instagram, smartphone, Penjualan.

\begin{abstract}
There are so many marketplaces available and so many methods of using e-commerce implementation so that it can make it easier for someone to improve their skills both in learning from sources and information obtained on curiosity and demonstrations. Aiming to provide knowledge of the resident villas of Casablanca villas. Social media applications as an example of Instagram include features that make it easier for someone to start a business through e-commerce media both in promoting products and using applications, and the public knows, therefore we take the approach of holding learning in the context of community service to socialize the application Instagram and apply it to mobile devices (smartphones) and laptops or device centers, a set of CPU tools used by residents of the Villa Casablanca Housing, Sawangan Depok, West Java. And we also provide training on the use of the Instagram social media application features on an Android smartphone, and we also provide information on how to use the application which aims to find out product marketing techniques. From this community service activity, residents of the Villa Casablanca Housing, Sawangan Depok, West Java.
\end{abstract}

Keywords: e-commerce, utilization of social media applications, Instagram, smartphone, sales

Correspondence author: Imam Himawan, imamhimawann@ gmail.com, Jakarta, Indonesia (c) (1) (3)

This work is licensed under a $C C-B Y-N C$ 


\section{PENDAHULUAN}

Perkembangan sistem informasi penjualan sudah merambah terhadap jenis teknologi yang dapat digunakan baik menggunakan device portable mobile atau device center seperti seperangkat alat computer dan server, informasi sangat pesat dirasakan masyarakat, kemudahan-kemudahan teknologi yang ditawarkan menjadikan pengguna merasakan banyak manfaat, seperti ponsel pintar android atau laptop yang dikenal dengan alat teknologi menawarkan media informasi yang didapat menggunakan aplikasi media social seperti halnya istagram. Ada banyak aplikasi yang ditawarkan untuk memsasarkan produk yang akan ditawarkan terhadap konsumen atau pembeli, aplikasi tersebut dinamakan Istagram, pada smartphone android terdapat fungsi aplikasi yang berjalan dengan baik, namun masih kurang maksimal karena beberapa fitur aplikasi belum dapat disediakan, oleh karena itu kami memilih aplikasi Istagram setelah menganalisis dari beberapa aplikasi Istagram yang berada di playstore.

Aplikasi Istagram belum banyak pengguna yang mengetahuinya, sehingga kemanfaatan dari fitur aplikasi tersebut tidak dirasakan oleh pengguna yang khususnya warga perumahan villa Casablanca Sawangan Depok.

Saat ini aktifitas seseorang untuk mempromosikan produk hanya dengan memposting gambar serta menunggu respon dari konsumen, sehingga proses waktu yang terbuang percuma jika hanya menunggu respon konsumen berharap adanya konsumen yang akan melakukan transaksi untuk membeli sebuah produk yang ditawarkan. Oleh karena itu kami mengadakan kegiatan Pengabdian Kepada Masyarakat (PKM) Pemasaran Produk Terhadap Aplikasi Istagram Kepada Warga Perumahan Villa Casablanca Sawangan Depok.

\section{METODE PELAKSANAAN}

Metode kegiatan PKM ini dilakukan secara daring atau online dengan kegiatan PKM ini dengan pembelajaran pemasaran produk terhadap pengguna mengenai peran dari aplikasi social media khususnya istagram dan juga melakukan pelatihan menerapkan aplikasi istagram sebagai media pemasaran. Serta penerapan cara pengguna fitur lelang terhadap aplikasi istagram yang mana fitur tersebut dapat dipraktekan pada smartphone.

Pelaksanaan kegiatan ini dilakukan dalam tiga tahap, yakni tahap persiapan, pelaksanaan dan evaluasi.

1. Tahap Persiapan. Pada tahap ini tim melakukan survei pendahuluan untuk mengetahui kondisi target kegiatan dengan menganalisis kondisi tempat yang akan digunakan, kondisi peserta yang akan diberikan perlakuan dan menyusun rancangan kegiatan yang akan dilakukan. Tahap persiapan selanjutnya tim menyiapkan bahan-bahan yang akan dijadikan materi presentasi.

2. Tahap Pelaksanaan yaitu, tim pelaksana melakukan Pelatihan kepada warga perumahan Villa Casablanca di Sawangan Depok dengan menyampaikan materi mengenai peran penguna sebagai aktor utama penerapan pengguna aplikasi istagram untuk menunjang pembelajaran warga.

3. Evaluasi dilakukan untuk mengukur tingkat keberhasilan suatu kegiatan pelatihan pembelajaran pemasaran lewat social media istagram. Evaluasi dilakukan 
berupa pemberian angket untuk mengetahui tanggapan peserta terhadap kegiatan pengabdian masyarakat.

\section{HASIL DAN PEMBAHASAN}

Jadwal dari kegaitan pendagdian masyarakat, adalah sebgai berikut:

\begin{tabular}{|c|c|}
\hline Waktu & Kegiatan \\
\hline Oktober 2020 Minggu ke 2 & $\begin{array}{l}\text { Pembahasan tujuan dan sasaran pengabdian } \\
\text { masyarakat dengan menyusun proposal }\end{array}$ \\
\hline Oktober 2020 minggu ke 3 & Penyerahan proposal \\
\hline \multirow[t]{4}{*}{ Oktober 2020 minggu ke 4} & Memastikan jobdesk tim \\
\hline & Survei tempat dan kebutuhan \\
\hline & Memastikan waktu pelaksanaan \\
\hline & Mengumpulkan data \\
\hline November 2020 minggu ke $1 \& 2$ & $\begin{array}{l}\text { Analis kebutuhan memilih system yang berbasis } \\
\text { social media dan untuk implementasi di lapangan }\end{array}$ \\
\hline November 2020 minggu ke $3 \& 4$ & $\begin{array}{l}\text { Persiapan materi dan peralatan } \\
\text { proses transfer knowledge warga setempat }\end{array}$ \\
\hline Desember 2020 minggu ke $1 \& 2$ & $\begin{array}{l}\text { Team mengevaluasi hasil kegiatan guna } \\
\text { mepersiapkan data }\end{array}$ \\
\hline Desember 2020 minggu ke $3 \& 4$ & Proses Penulisan laporan pengabdian masyarakat \\
\hline
\end{tabular}

Materi yang dibawakan pada kegiatan pelatihan adalah sebagai berikut :

1. Internet Sehat

Mensosialisasikan program internet sehat yang digulirkan oleh Kementrian Komunikasi dan Informatika Republik Indonesia yaitu pemanfaatan internet dalam belajar, bekerja, berkomunikasi, berbelanja dan aspek lain yang menggunakan surel, jejaring sosial, pesan instant, dan media online (Kominfo : 2013).

Internet memiliki dampak positif dan negatif, oleh karena itu Undang Undang Internet dan Transaksi Elektronik pada tahun 2008 yang dikenal dengan UU ITE nomor 11 Tahun 2008 dan direvisi pada nomor 19 Tahun 2016 menjadi payung hukum untuk keamanan dan kenyamanan berselancar di internet.

2. Aplikasi social media Instagram

Instagram adalah salah satu jaringan sosial yang paling populer. Sejak berada di bawah naungan perusahaan induknya, yaitu Facebook, ada banyak inovasi yang dilakukan Instagram untuk memenuhi kebutuhan penggunanya. Saat ini, menggunakan Instagram telah memiliki banyak fitur pendukung sehingga Anda bisa melakukan berbagai kegiatan promosi maupun meningkatkan brand awareness. Berikut ini social media campaign di Instagram yang perlu Anda lakukan untuk mendapatkan lebih banyak audiens. https://www.redcomm.co.id/knowledges.

3. Perangkat Lunak

a. Instagram pada smartphone android

Para pengguna sistem operasi Android, Instagram terdapat pada google play yang dapat di unduh secara gratis. Langkah-langkah penggunaan Instagram pada smartphone android adalah sebagai berikut :

1) Membuka Google Play dan ketikan Kroha pada kotak search lalu tekan tombol install seperti gambar berikut : 


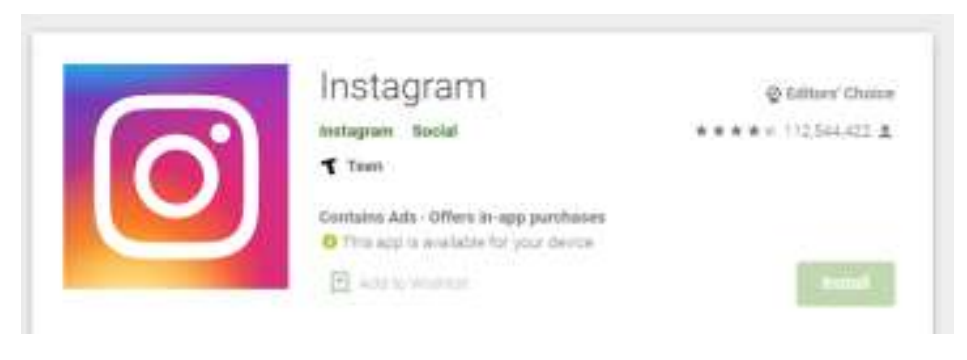

Gambar 1.1 Proses memilih aplikasi

2) Kemudian tunggu proses download dan instalasi selesai. Lalu tekan open atau buka seperti yang ditunjukan oleh gambar berikut :

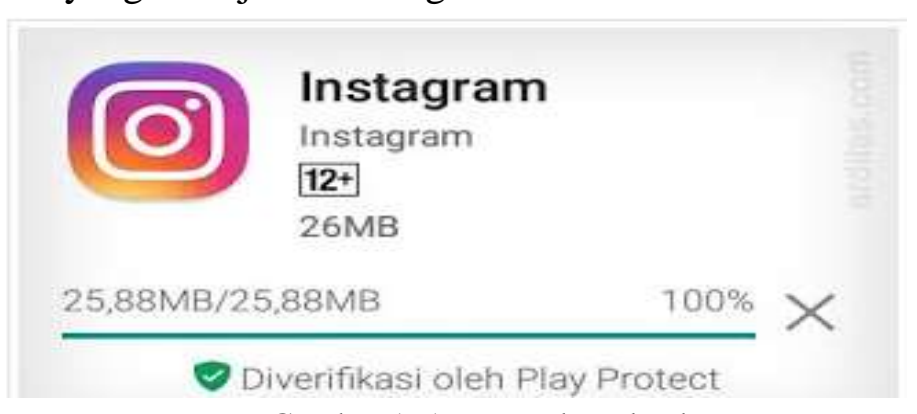

Gambar 1. 1 Proses download

3) Kemudian proses download selesai, maka dapat menekan tombol berwarna hijau yang bertuliskan buka, seperti gambar berikut :

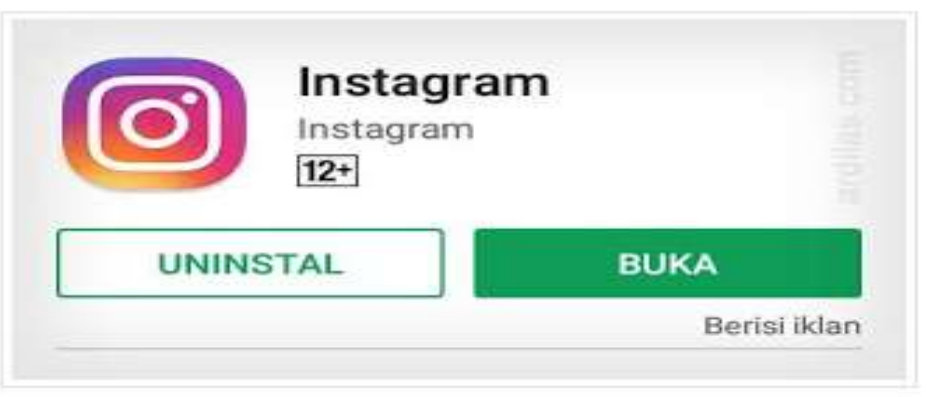

Gambar 1. 2 Membuka aplikasi instagram

4) Kemudian isi form, lalu tekan tombol Daftar seperti gambar berikut :

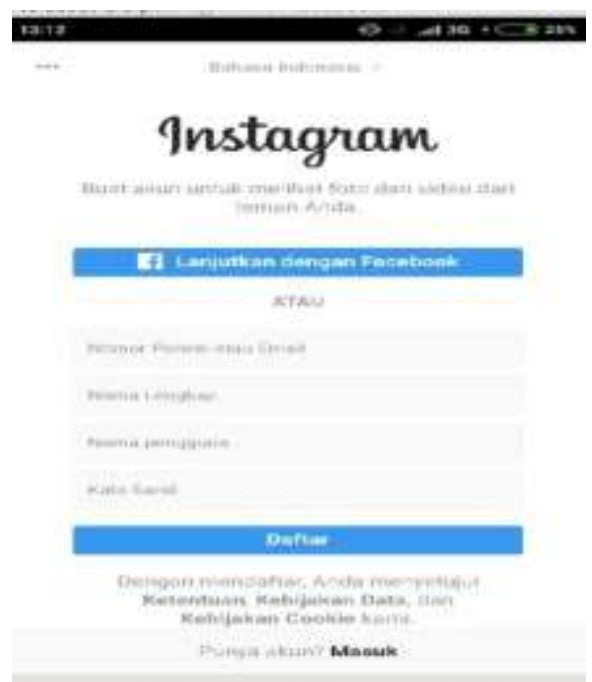

Gambar 1. 3 Proses Daftar 
5) Ada dua cara sign up (register) account for Instagram Android, yaitu dengan Facebook dan Email atau Nomer handphone. Dari dua cara pendaftaran tersebut, caranya hampir sama. Di sini kita akan bahas keduanya. Untuk penjelasan ada di bagian bawah, seperti yang ditunjuk gambar berikut :

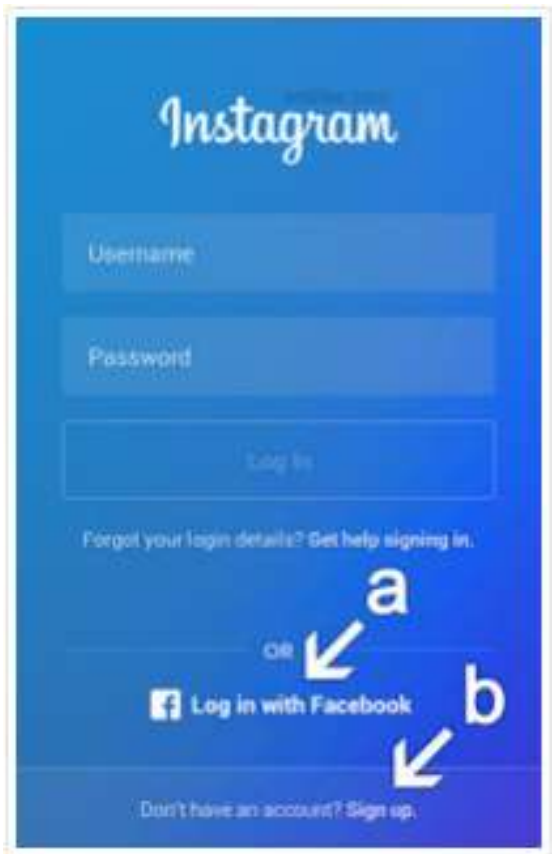

Gambar 1. 4 Proses Login

6) Dengan masukan username dan password dengan benar maka home page tampilan aplikasi instgaram sebagai berikut, seperti yang ditunjuka oleh gambar berikut :

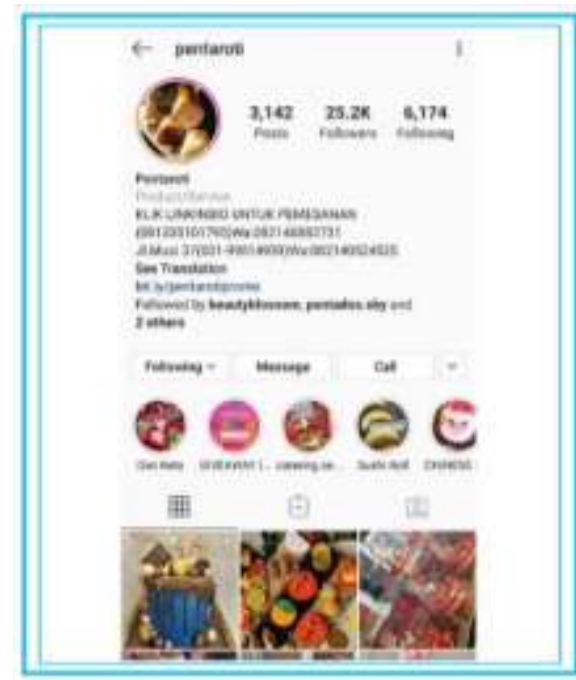

Gambar 1. 5 Home Page Instagram

7) Setelah itu anda sudah dapat menggunakan aplikasi Instagram dengan bisa memanfaatkan fitur fitur yang tersedia oleh sistem, Dengan menekan gambar profile, kemudian terdapat informasi pilihan langsung maka instagram akan menampilkan video live conference secara langsung pemilik akun dapat berinteraksi terhadap customer, sebagai ujicoba akan mencoba fitur live serta 
untuk memasarkan produk yang akan di jual, seperti terlihat pada gambar berikut:

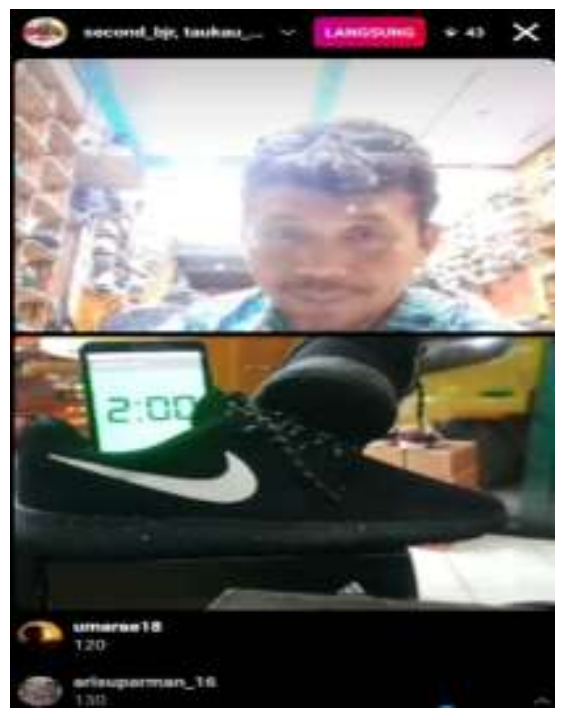

Gambar 1. 6 Proses Langsung penjualan

Dengan memanfaatkan teknologi maka penjual terasa mudah untuk memberikan informasi yang akan disebarluaskan terutama terhadap produk yang akan di perjual belikan.

\section{SIMPULAN}

Internet semakin berkembang dan juga teknologi dari smartphone, maka pengguna teknologi harus berevolusi dan beradaptasi untuk menghadapi konten-konten yang disajikan. Peran penjual dan pembeli dapat memanfaatkan aplikasi yang tersedia oleh developer, masyarakat umum sangat membutuhkan informasi pengguna aplikasi penjualan khususnya yang bergerak dibidang penjualan dalam perkembangan metode penjualan dalam masa sistem informasi saat ini, sehingga Masyarakat dapat menggunakan smartphone dan berselancar di internet dengan aman dan nyaman terutama untuk pelaku penjual dan pembeli, khususnya penjual terhadap produk serasa berada di gengamanaya tidak perlu harus membuat virtual office dikarenaka semua dapat dikelola dan sebaliknya pembeli hanya bisa membelinya lewat smartphone dengan media aplikasi instagram yang tersedia terhadap akun penjual selaku pembeli dapat berintekasi, dengan melihat produk yang ditawarkan sampai terjadi transaksi, dan semua itu terjadi dengan menggunakan smartphone .

Dan dengan hadirnya UU ITE masyarakat khususnya baik penjual dan pembeli dapat bekerja sama, ada pun jika merasa dirugikan dapat diselesaikan dengan kekeluargaan, namun jika tidak bisa diselesaikan dengan metode kekeluargaan,, baik penjual dan pembeli dapat melaporkan terhadap pihak berwajib dengan pasal UU ITE, diharapkan lebih peduli pada dunia maya khususnya dengan konten-konten yang berujung penipuan dan diharapkan jangan ragu untuk melaporkan kepada pihak berwenang jika terdapat penyimpangan teknologi. 


\section{DAFTAR PUSTAKA}

Akhlis. (2011). 10 Hal yang Harus Ada dalam Situs Bisnis. Tersedia di www.ciputraentrepreneurship.com.

Alma, Buchari. (2011). Manajemen Pemasaran dan Pemasaran Jasa. Bandung : Penerbit Alfabeta.

Hermawan, Agus. (2012). Komunikasi Pemasaran. Jakarta: Penerbit Hikmah (PT Mizan Publika)

Kementrian Komunikasi dan Informatika., (2013), Internet Sehat dan Aman, https://kominfo.go.id/index.php/content/detail/3303/Internet-Sehat-dan-Aman-INSAN-/0/internet_sehat, Di Akses Januari 2019.

Kementrian Komunikasi dan Informatika, (2016),Undang-Undang No. 19 Tahun 2016 Tentang Perubahan Atas Undang-Undang Nomor 11 Tahun 2008 Tentang Informasi dan Transaksi Elektronik, https://web.kominfo.go.id/sites/default/files/users/4761/UU\%2019\%20Tahun\%2 02016.pdf, diakses 16 Januari 2019. 